\title{
Família e propaganda - imagem restaurada: um exercício de leitura de imagens
}

\author{
Family and advertising - restaured image: an exercise of image reading
}

\section{Familia y propaganda - imagen restaurada: un ejercicio de lectura de imágenes}

Ireno Antônio Berticelli*

\section{Resumo}

\begin{abstract}
Este artigo é uma análise cultural da família, assim como ela é vista numa/pela propaganda de um modelo de automóvel. Insere-se na proposta dos Estudos Culturais (ECs), neste caso, com fins educativo-pedagógicos de leitura de imagens. O método de análise é predominantemente qualitativo, no sentido de que a verdade buscada se insere essencialmente no campo da interpretação e do ensaio crítico: prática corrente de método, nos ECs. Dentre as metodologias mais correntes nos ECs, escolhi a que Barker (2008) caracteriza como abordagem textual. A mesma autoridade deixa claro que a perspectiva teórica da semiótica ocorre normalmente em autores dos ECs, de modo que eu mesmo, neste estudo, faço incursões semióticas. O texto-imagem encerra ideologias e mitos - mito proposto por uma propaganda de fundo ideológico. A imagem se constitui num texto revelador de intenções/mensagens cuja significação é por ela mediada de modo complexo, numa dialética de mostrar e esconder, de dizer e silenciar, onde o poder se exerce em nome de uma vontade que se materializa na linguagem textual: uma fotografia. Trata-se do exercício da leitura de um texto não convencional, cuja presença é uma das características marcantes de nosso tempo: a imagem. Nela, lemos sobre um padrão cultural de família através de um modelo de automóvel, em que busco as forças de persuasão que a imagem exerce, na produção da subjetividade de uma família "restaurada".
\end{abstract}

Palavras-chave: leitura de imagens; leitura; imagem como texto.

\section{Abstract}

This article is a cultural analysis of the family as it is seen in an/through an advertising of a car model. It is inserted in the proposal of Cultural Studies (CS), in this case, for educational-pedagogical purposes of image lecture. The method of analysis is prevailingly qualitative, in the sense that the sought truth is essentially inserted in the field of interpretation and of the critic essay: a current practice of method, in the CS. Among the methods most frequent in the CS, I have chosen the one that Backer (2008) characterizes as textual approach. The same authority makes clear that the theoretical perspective or semiotics occurs normally in authors of CSs, so that myself, in this study, make semiotic inroads The image-text, in this case, contains ideologies and myths - the proposed myth by an advertisement ideologically based. The image is a discloser text of intentions/messages whose signification is mediated by it, in a complex way through a dialectical of to show and to hide, of to say and to mute, where

Recebido em: 12/05/2019 - Aprovado em: 15/04/2021

http://dx.doi.org/10.5335/rep.v28i1.9437

Doutor em Educação pela Universidade Federal do Rio Grande do Sul (UFRGS). Mestre em Educação: Ensino Superior pela Universidade Regional de Blumenau (Furb). Docente do Programa de Pós-Graduação Stricto Sensu (Mestrado em Educação) e no Programa de Pós-Graduação Stricto Sensu em Ciências da Saúde (Doutorado em Ciências da Saúde) da Universidade Comunitária da Região de Chapecó (Unochapecó). Orcid: https://orcid.org/0000-0003-3498-9999. E-mail: ibertice@unochapeco.edu.br 
the power is exerted in the name of a will that is materialized in textual language: a photography. This study is an exercise of lecture of a not conventional text whose presence is one of the most remarkable characteristics of our time: the image. In it we read about a family cultural pattern through a car model, in which I search for the forces of persuasion that the image exercises, in the production of the subjectivity of a "restored" family.

Keywords: image reading; reading; image as text.

\section{Resumen}

Este artículo es un análisis cultural de la familia, así como ella es vista en/por una publicidad de un modelo de coche. Se incluye en la propuesta de los Estudios Culturales (EC), en este caso, con fines educativo-pedagógico de lectura de imágenes. El método de análisis es predominantemente qualitativo, em sentido de que la verdade buscada se inserta essencialmente en el ámbito de la interpretación y el ensayo crítico: práctica común em los EC. Entre las metodologías mas comunes em los EC, elegí aquella que Backer (2008) caracteriza como enfoque textual. La misma autiridad deja claro que la perspectiva teórica de la semiótica ocorre normalmente em los autores de los ECs, de modo queyo mismo, em este estudio, hasgo incursiones semióticas. El texto-imagen, em este caso, contiene ideologias y mitos - el mito propuesto por uma publicidad ideológica. El método de análisis es predominantemente qualitativo, em sentido de que la verdade buscada se inserta essencialmente en el ámbito de la interpretación y el ensayo crítico: práctica común em los EC. Entre las metodologías mas comunes em los EC, elegí aquella que Backer (2008) caracteriza como enfoque textual. El texto-imagen, em este caso, contiene ideologías y mitos - el mito propuesto por uma publicidad ideológica. La imagen se constituye en un texto revelador de intenciones/mensajes cuyo significado es por ella mediada de modo complejo, en una dialéctica de mostrar y ocultar, de decir y silenciar, adónde el poder se ejerce en nombre de una voluntad que se materializaa en el lenguaje textual: aquí, una fotografía. Este estudio es un ejercicio de lectura de un texto no convencional cuya presencia es una de las características de nuestro tiempo: la imagen. En ella leemos a respecto de un estándar cultural de familia, a través de un modelo de coche em la que busco las fuerzas de persuasión que la imagen exerce em la productioón de la subjectividad de uma familia "restaurada".

Palabras clave: lectura de imágenes; lectura; imagen como texto.

\section{Introdução}

Passados mais de 22 anos da publicação do número da revista Quatro Rodas, da qual extraí uma imagem para realizar, em torno e a respeito dela, um estudo cultural, há de convir que as condições sociais e conceptuais de "família" sofreram grandes transformações, principalmente com a disseminação generalizada dos meios eletrônicos de informação como a internet e os artefatos como os computadores, os celulares, os tablets e outros gadjets semelhantes. Mesmo a TV digital trouxe profundas modificações ao acesso de informação. Com isto, o processo de homogeneização cultural, em alguns aspectos, se tornou uma realidade corrente. Mesmo assim, mutatis mutandis, a imagem que escolhi para análise não perdeu seu vigor informativo/deformativo/reformativo/performativo.

$\mathrm{Na}$ intencionalidade deste estudo, a metodologia lhe é constitutiva, ou seja, leva diretamente à compreensão das significações do signo, neste caso, uma fotografia, 
com seus elementos que a compõem. Os Estudos Culturais (ECs), havendo mesmo muitos "caminhos investigativos" (não raro até conflitantes) propostos pelos múltiplos autores que neles operam, a meu alvitre, mantém algumas características que são constantes. Assim, admitem a complexidade dos fenômenos/artefatos que analisam. Propõem-se a produzir conhecimentos com relevância social (PINA, 2003). Por outro lado, a pretensão de um estudo cultural nunca opera como se o conhecimento fosse neutro. É sempre um posicionamento político e ideológico. A ideologia, diferentemente do conceito marxista, é parte constritiva de todo discurso. Não é oculta em intenções escusas, mas "visível", como parte mesmo que caracteriza qualquer texto/ discurso. É desta maneira que a ideologia é entendida por mim, neste texto. Barker (2008), importante nome, neste campo, confirma esta posição. Tal como em Stuart Hall (1972), a perspectiva que orienta os ECs é a articulação entre as preocupações teóricas com as inquietações concretas. $\mathrm{E}$ a questão da ideologia, ganha intensidade, sob a compreensão aqui defendida, quando os autores dos ECs começaram a dar sustentação argumentativa às suas produções com Michel Foucault. Assim, este estudo busca a articulação entre os valores meramente capitalistas com os valores sociais/ familiares (as posições hierárquicas includentes e excludentes ocupadas pelos personagens da propaganda em análise). Na trama do pensamento deste artigo, pode-se identificar rastros de política cultural, mais uma característica teórico-metodológica dos ECs. Ou seja, a ordem em que se distribui o poder através do artefato (o automóvel) e os diversos personagens que completam o quadro analisado. São visíveis, nele, o poder do mercado articulando-se com a cultura popular e a quase veneração dos "carrões", tão ligados ao conceito de status social.

O estudo tem por objetivos:

a) fazer um exercício de leitura de imagem, com fins pedagógico-educativos para discentes e docentes;

b) analisar uma peça publicitária, decodificando seus componentes materiais e imateriais (simbólicos), de sorte a propiciar a possibilidade de compreender processos de produção de subjetividades, pela força ilocucionária da imagem-texto;

O significado de texto e leitura, na contemporaneidade, alcança uma amplitude muito maior do que se supunha, a bem menos de um século atrás. Ou seja, o mundo é texto que pode ser lido a partir de muitos horizontes de visão e de interpretação. E nunca, como na contemporaneidade, a imagem ocupou tamanha significação, tanto em tempo, quanto em espaço, na vida cotidiana de todas as pessoas, sob todas as idades e condições socioeconômicas, políticas, geográficas. Na educação, a leitura de imagens se tornou uma demanda emergente e aguda. Desde a mais tenra 
idade, as crianças manipulam milhões de imagens, em sempre maior profusão, com sempre maior complexidade e apelo. E os adultos também estão neste mesmo jogo. O mundo digital faz parte constitutiva das identidades contemporâneas. As novas gerações já nem conseguem mais imaginar o mundo sem televisão, sem computadores, sem iPhones, sem tablets e numerosos outros meios técnicos de comunicação e entretenimento, de trabalho cotidiano/diuturno, em que o mundo se expõe em profusão de cores e imagens que moldam as identidades contemporâneas. Tempo e espaço se fundem no virtual imagético e a educação mesma é, com isto, ressignificada. O tempo e o espaço do aprender foram inteiramente ressignificados pelo acesso ao conhecimento, independentemente de lugar, de espaço físico, como há tão pouco tempo fazia parte do cotidiano das pessoas. Examinem-se, por exemplo, os materiais escolares, incluídos, nisto, os manuais de 1960 para trás para constatar quão pouco havia neles de imagens. E se havia, eram, em geral, imagens por vezes precárias e desprovidas de cor. Sendo imagens reais, sua profusão e difusão era muitíssimo ou quase infinitamente limitada se compararmos os meios para tal com os atuais meios eletrônicos que oferecem a virtualidade. O virtual, hoje, se confunde com o real (não é seu contrário, nem lhe é contraditório), com a diferença que a multiplicação de imagens se faz à velocidade inimaginável daqueles tempos. A preocupação de Walter Benjamin expressa em A obra de arte na era da reprodução técnica (2013) ainda não subentendia, obviamente, o que acontece, hoje, com as novas possibilidades de reprodução sempre mais perfeita. Vivemos o tempo em que se nos impõe refletir sobre $A$ imagem na era de sua reprodutibilidade eletrônica, conforme tematizou, em sua dissertação de mestrado, Ruy Sardinha Lopes (1995, p. 8), que inicia sua introdução dizendo: "A pletora de imagens constitui um dos traços marcantes da cultura contemporânea. A se dar ouvidos à crítica da cultura, podemos afirmar que a percepção contemporânea tem nas imagens seu elemento fundante".

Este estudo pretende ser um exercício de leitura de imagem, quando os educadores necessitam familiarizar-se com este mundo novo das imagens em profusão, em que a propaganda ocupa espaço significativo na vida de todos os cidadãos, de todas as idades. A imagem adotada para o estudo foi escolhida propositadamente de um contexto histórico afastado do presente, para manter a necessária e desejável distância de qualquer conotação de marketing, pois este não é, em absoluto, o objetivo do artigo.

A fotografia, que nunca é "[...] simplesmente uma visão capturada do outro, mas antes um lugar dinâmico onde muitos olhares e pontos de vista se cruzam" (LUTZ; COLLINS, 1994, p. 363), abre inúmeras possibilidades de manipular o 
"real" para torná-lo virtual, no sentido de ser possível adequar qualquer "realidade" a um quadro cultural típico. E a arte/ciência da propaganda/do marketing sabe muito bem disto.

A produção publicitária se tornou um elemento de produção de identidades que ocupa diuturnamente o imaginário social. A propaganda captura os desejos e os sonhos dos sujeitos, obedecendo, inclusive, as diferenças de gênero e de idade das pessoas. Faz uso de uma trama complexa de conhecimentos que vão da psicologia, à antropologia e à arte gráfica extremamente sofisticada, hoje, graças aos meios digitais. A cada dia, o virtual e o real se aproximam mais e mais. Já vivi a experiência de aguardar um pouco para entrar numa agência de automóveis, pensando que o vendedor estivesse junto à entrada conversando com uma família cliente. Ao invés dito, era uma propaganda da loja colada à parede envidraçada. A produção publicitária consegue associar a preconizada excelência dos produtos à excelência das pessoas que os consomem. $\mathrm{O}$ virtual "[...] tem somente uma pequena afinidade o com o falso, o imaginário ou o ilusório" (LÉVY, 2011, p. 12). Assim, a peça publicitária que ora analiso, excita vários sentimentos dos possíveis consumidores do modelo de automóvel proposto: a família ideal/idealizada, o vestuário ideal/idealizado, a distribuição ideal/idealizada do poder, no seio de uma "família ideal", no mínimo tão ideal/idealizada como o próprio automóvel proposto oferecido à venda. Para compreender a mensagem da peça publicitária como um todo, há que atentar para cada elemento que a compõe: elementos materiais e imateriais. $\mathrm{O}$ apelo publicitário se distribui sobre todos esses elementos constitutivos da peça que produz, quando ela é resultado de efetivo conhecimento do assunto. Assim, a imagem publicitária objeto desta análise há que ser desdobrada em seus vários elementos materiais e imateriais constitutivos, sem perder de vista o conjunto que produz o restauro da família contemporânea.

Através da análise de uma propaganda fotográfica que começa na capa da revista Quatro Rodas, n. 38 (1998) e se estende por algumas páginas mais, tentarei ver a metamorfose da família urbana, mas pelo avesso, ou seja, não o processo de esvaecimento e desintegração por que passa. Pelo contrário: perquiro a imagem restaurada da família. Restaurada pela propaganda de automóveis (neste caso, alguns modelos da Fiat). Ainda que a revista faça a avaliação dos vários modelos de automóveis, mantém-se (financeiramente) da propaganda desses mesmos automóveis. Bem por isto pode, a um momento, estampar uma imagem fotográfica em que as legendas dizem tratar-se do melhor automóvel e, em outro momento, na avaliação, poderá estar apontando falhas e defeitos quanto a espaço, equipa- 
mentos, desempenho, consumo, design ou outras questões mais. A mim interessa, neste momento, o meu tema ou, seja, buscar gazes, olhares lançados pelo visor das câmeras fotográficas sobre a família, em função de propaganda de automóveis da Fiat que, segundo a hipótese que adotei, fazem uma restauração de sua imagem. Tentarei verificar quais são os traços restaurados e quais são os traços mantidos, de acordo com a tradição da família tipicamente burguesa, a família-padrão. Aliás, família e fotografia são coisas que andam quase sempre juntas: é costume, sobretudo na cultura ocidental, fotografar constante e persistentemente a família. A família é produzida pela imagem fotográfica: fotos de casamento, de batizado, de festas, de aniversários (com ênfase no primeiro), enfim, até praticamente a morte, a fotografia acompanha a família. Incluída nisto aquela foto tumular com algum epitáfio, às vezes e, na maior parte das vezes, simplesmente a foto do casal. A fotografia do casal remete à saudade dos filhos sobreviventes. São bem menos comuns as fotografias tumulares de indivíduos. São inúmeras as oportunidades em que as fotografias e retratos instituem materialmente o conceito abstrato de família. Como as flores, as fotografias acompanham o homem/a mulher do berço ao túmulo.

O estudo se desdobrará em mais quatro seções. A primeira lança um primeiro olhar sobre a peça publicitária, com vistas a entendê-la sob o ponto de vista teorético e sígnico. Na segunda, trata-se do texto como hipertexto. Na terceira, diferenciam-se texto e fotografia. Finalmente, a quarta seção versará sobre a imagem no contexto do processo educacional.

\section{A fotografia transcende a referência}

Quando se pretende fazer retrospectivas de famílias, dificilmente não faz parte do processo a apresentação de fotografias. Há muito tempo, o programa de TV Domingão do Faustão apresentado por Fausto Silva, na Rede Globo, vem refazendo históricos de artistas, onde a apresentação da família é uma constante. Velhas fotos familiares são mostradas ao olho das câmeras que, por sua vez, as mostram aos nossos olhos. Assim:

O papel crucial da fotografia no exercício do poder está em sua habilidade de oportunizar estudo acurado do Outro e promover, conforme palavras de Foucault, "olhar normalizador", uma vigilância que torna possível qualificar, classificar e punir. Ela estabelece sobre os indivíduos uma visibilidade através da qual os diferenciamos e os julgamos (LUTZ; COLLINS, 1994, p. 366). 
A fotografia é, para Foucault, o recurso que estabelece interligação entre conhecimento e poder. A fotografia funciona como algo bem mais forte que uma simples referência. A seguir, a Figura 1 apresenta o objeto de estudo deste artigo.

Figura 1 - O carro ideal para a sua família

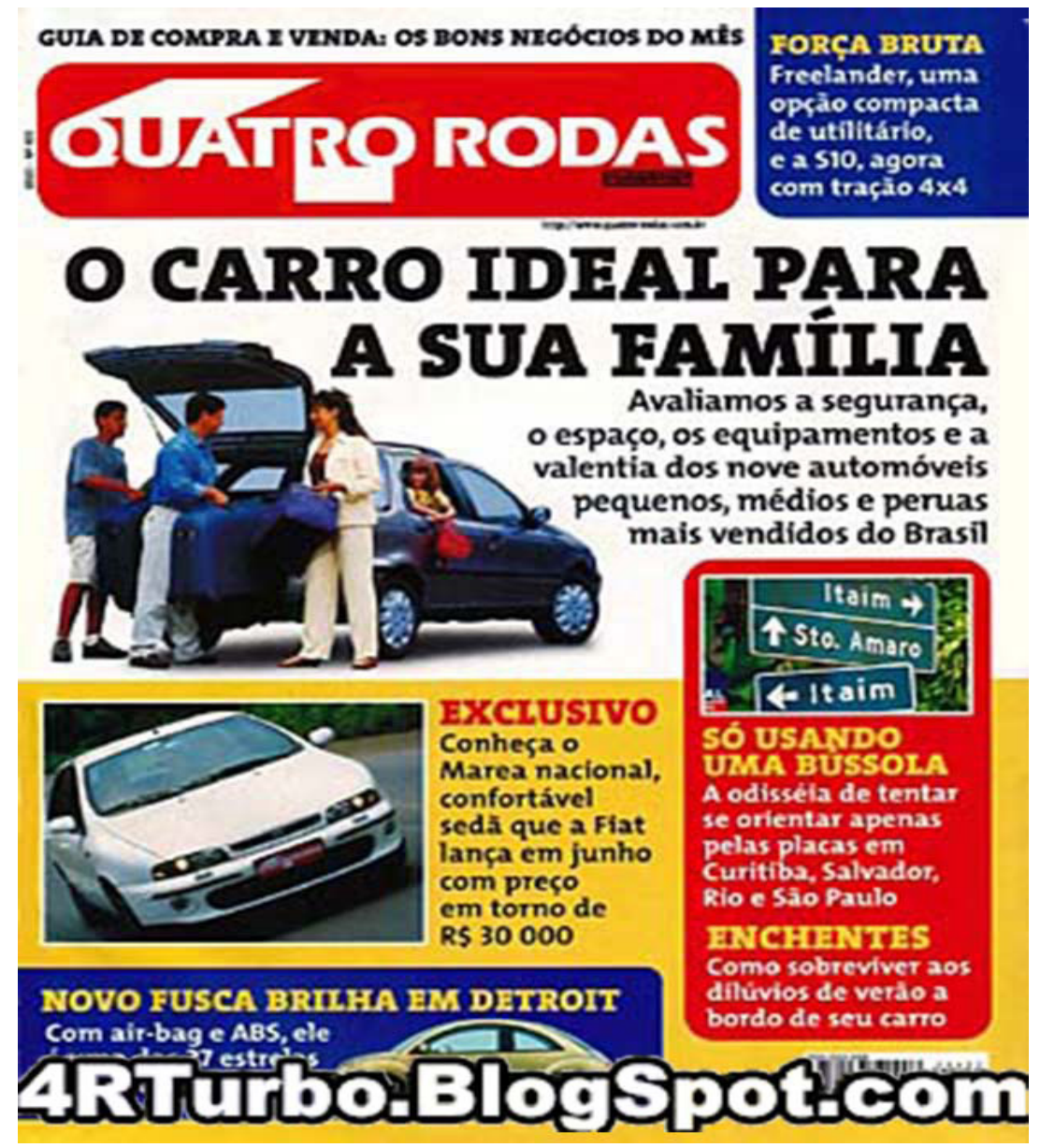

Fonte: capa da revista Quatro Rodas, n. 38, 1998.

Não se tendo a si mesmos como disciplina acadêmica, os ECs, não por acaso, reúnem intelectuais estudiosos da Literatura, da linguística, da Sociologia, da História, da Antropologia, da Comunicação, da Geografia, dos Estudos Fílmicos, da Psicologia, da Educação e da Filosofia (BAPTISTA, 2009). Na verdade, por caminhos muito diferentes entre si, convergem na busca das relações a que me referi adrede: o liame entre o mundo concreto dos artefatos resultantes de qualquer uma 
das áreas de conhecimento arroladas, com a prática ou micropráticas políticas. A imagem de "O carro ideal para a sua família", tanto produz a identidade de um carro ideal, quanto de uma "família ideal", como consequência direta ou como causa (o carro) e efeito (a família ideal" que, claro, não é para quem quer, mas para quem pode e tem interesse nisso. Afinal, está aí a "imagem restaurada" da família contemporânea evanescente: metamorfose da família urbana em desagregação histórica transmudada numa família "hierarquicamente correta", sob os melhores padrões burgueses. A compreensão sociológica e a compreensão antropológica ser entrelaçam na imagem em estudo.

A ilustração referente ao Palio Weekend coloca em primeiro plano uma família. É de se notar que o homem, o pai da família, representa bem o chefe da família, o pátrio poder, na melhor tradição da família clássica. Sua posição central recebe $o$ olhar da mulher (da mãe de família) e do filho. O pai comanda a cena: introduz as malas no bagageiro do automóvel. A mulher se coloca na cena como quem espera que o marido apanhe de suas mãos a mala. $\mathrm{E}$ o filho também depende de seu pai para completar seu gesto de colocar a mala no bagageiro, enquanto a filha, que é menor/criança, já está no interior do automóvel, mas com a bolsa na mão como quem solicita que seja colocada no bagageiro.

A identificação entre as pessoas e a Weekend se dá em grau muito mais elevado com as do sexo masculino: pai e filho usam camisa da mesma cor que a da Weekend: o azul. Aliás, olhando para o quadro fica-se um pouco tentado a exclamar "Alles blau!" - "Tudo azul!" (em alemão). A harmonia entre o automóvel e a família parece ser a mais perfeita possível! O pai é extremoso. Encarrega-se da tarefa mais pesada. O filho, atrás dele, olha confiante e levemente sorridente, enquanto a mãe e a filha também expressam sorriso de satisfação que se confunde com a satisfação pelo novo automóvel ou, igualmente, pela visão do pai que distribui/irradia segurança e no filho: promessa grandiosa de futuro. Trata-se de uma família idealizada para o contemporâneo: homem, mulher e dois filhos. O primeiro, na ordem cronológica de nascimento, é homem e o segundo é mulher (ainda criança), a realização burguesa de um sonho: ter dois filhos nesta ordem. A identificação menor das duas mulheres, uma criança e sua mãe, com a Weekend é muito bem compensada pela segurança que oferecem: para a mulher, o marido e para a criança a Weekend, no interior da qual já se encontra muito bem abrigada. O filho está no caminho do pai que, pelo mérito do trabalho garante uma continuidade segura do clã.

O vestuário da família, como ilustração, é altamente significativo: distinção, sem cair no clássico. Esportividade, sem excessos. O pai de família usa sapato es- 
porte, mas escuro; calça e camisa jeans, o que conota ainda, passados mais de 22 anos, atualidade, esportividade, mas com moderação. Se utilizasse tênis, como o filho, perder-se-ia a necessária seriedade para corresponder a uma van: carro tipicamente de família ou, como diz a legenda de capa da revista em análise, "O carro ideal para a sua família". Aliás, é de notar que não se diz apenas "Carro ideal para $a$ ", mas diz "para a sua família”, o que garante a plenitude da proprietas (propriedade), o proprium (a coisa própria) ou seja, a família e a Weekend: propriedade e pátrio poder.

As cores mais vivas e alegres são reservadas, em primeiro lugar, para a criança: amarelo da camiseta e vermelho de bolinhas para a mochila, diadema e suspensórios e, provavelmente, o restante da roupa, que não aparece toda. O moço (filho) se projeta, de certa forma, no pai, pela utilização da mesma cor da camisa a cor da bermuda correspondendo aproximadamente à cor da calça do pai. Trata-se do herdeiro das virtudes paternas, o sucessor na ordem da tradição. A mãe usa um conjunto creme: cor delicada, como convém a uma mulher que acompanha um proprietário de uma Weekend: sem ostentação de joias e colares: trata-se de família de classe média. Todos os membros da família exibem corte moderado do cabelo.

A fotografia forma um quadro extremamente clean. Nenhum elemento trai a finalidade principal que é mostrar "o carro ideal para a sua família". Todos os membros da família são emoldurados pela Weekend. Para todos ela oferece conforto e segurança. Nenhum olhar das pessoas se dirige ao espectador do quadro. Ainda que os olhares se dirijam basicamente ao pai de família, todos os membros familiares fazem convergir seu gaze (olhar) para o centro principal de interesse: o porta-malas da Weekend, de maneira a não distrair os espectadores da propaganda e, por outro lado, para focar a abundância que o porta-malas oferece.

Todos os membros da família da ilustração deixam transparecer excelente saúde, um desenvolvimento físico saudável. A mulher, ainda que em posição discretamente secundária e dependente em relação ao marido, é alta e de formas harmônicas. Trata-se, pois, de uma família em que os valores da mulher não sofrem maiores ameaças de ofuscamento. Como família burguesa ideal ${ }^{1}$, é claro que não se poderia dar excessivo destaque à emancipação feminina. Assim, a mala que ela carrega é menor. A do moço parece ter as mesmas proporções que a do pai. Caso contrário, não se justificaria a robustez de sua juventude, a legitimidade de filho herdeiro das virtudes de uma família idealizada que optou por um carro ideal. $\mathrm{E}$ a filha também é menor que o filho, mantendo-se a hierarquia, tal como convém. $\mathrm{O}$ quadro se constitui uma metáfora perfeita em relação ao carro. Ou seja: carro 
ideal $=$ família ideal . Ou, ainda, inversamente: família ideal $=$ carro ideal . O signo se constitui à medida que se constituem significante e respectivos significados. Traço por traço, a propaganda da Weekend recompõe a família classe média bem-sucedida, de bom gosto, bem constituída, bem disciplinada e educada: uma nobre hierarquia natural. A disciplina aparece na ação e postura hierárquica de cada membro. O pai, ao centro. A mãe, logo a seguir (repare-se a ordem em que as malas serão colocadas no bagageiro), com especial destaque para a proteção que a mulher necessita (mala menor, de peso menor, mais delicada - é de tecido -, mais suave), vestida em cores mais leves, mais suaves, mais iluminadas (mais etéreas), bem por isto, no conjunto do quadro não há como não perceber o sexo frágil. Os próprios sapatos que usa têm detalhe em cor mais clara. O moço já vai adiantando sua tarefa, não pela ordem de precedência, mas pela ordem do vigor físico: já conseguiu introduzir metade da mala no bagageiro, como o pai, ainda que fique em posição menos confortável, o que determinará sua espera para que o pai complete primeiro sua tarefa. Por fim, mais a distância e mais isolada, a criança (uma menina), que não poderia faltar para completar a família idealizada, talvez ainda não entenda estar diante do "carro ideal para a sua família". Por isto mesmo, ocupa o interior do caro, uma extensão uterina da proteção materna, garantida pelo vigor paterno.

\section{A leitura da propaganda: um texto/hipertexto}

Naturalmente, estamos de acordo com Barthes (apud LUTZ; COLLINS, 1994, p. 368) quando afirma que "[...] fotografia não é apenas percebida, recebida, ela é lida, conectada mais ou menos conscientemente pelo público que a consome a um estoque tradicional de signos". Afinal, uma fotografia (uma imagem) é um texto/ hipertexto que permite leituras. Não apenas uma leitura. Como os desejos são diferentes, as leituras lhes correspondem. Desejo e leitura estão intimamente ligados. $\mathrm{O}$ olhar dos diversos leitores obedece à diversidade dos elementos culturais que o constitui. Elementos culturais e modelos estruturam, por sua vez, o olhar dos leitores. Modelos ligados a gênero, a sexo, a etnia definem olhares que põem à mostra determinados elementos da mesma fotografia ou os escondem. Isto vale para o próprio olhar do que cria um texto (lato sensu): padrões e modelos culturais conduzem o olhar para determinados pontos que vão se tornar salientes. Assim, o patriarcalismo de nossa cultura ocidental, a pretensa supremacia da raça branca, a domesticação da mulher e outros traços culturais determinam destaques nos textos como as fotografias, as imagens em geral produzidas pelo olhar do fotógrafo, 
a quem se encomenda e se paga a fotografia transformada em propaganda. "Em Linguística”, diz Barthes (1997, p. 46), “[...] a natureza do significado deu lugar a discussões sobretudo referentes a seu grau de 'realidade'; todas concordam, entretanto, quanto a insistir no fato de que o significado não é uma 'coisa', mas uma representação psíquica da 'coisa". Saussure (1995) também concorda com isto e põe em destaque a natureza psíquica do significado ao denominá-lo conceito. A fotografia produz este efeito que ultrapassa a realidade, a materialidade das coisas fotografadas. Assim, uma família idealizada remete ao carro ideal - se é ideal é conceptual, é ideia, produção dos sujeitos. Ainda que o processo de compreensão a que remete "o carro idealizado para a família idealizada" seja um retorno a Platão, a melhor maneira de tornar imperecível, eterno, perfeito o objeto de desejo é enviá-lo para o mundo das ideias, porquanto o mundo material é dele apenas pálida imagem, imperfeita imitação, o que poderia pôr à mostra suas imperfeições. Assim, no mesmo processo, envia-se (joga-se, lança-se: jactare, da língua latina), no caso que estamos analisando, o objectum (Palio Weekend) e o subjectum para o mundo ideal, onde tudo é perfeito. Mas para isto, há que se retocar profundamente a imagem evanescente e defeituosa da família dita moderna, sobretudo urbana. E isto, a fotografia em discussão faz muito bem. "O signo é uma fatia (bifacial) de sonoridade, visualidade etc.”, diz Barthes (1997, p. 50). "A significação pode ser concebida como um processo; é o ato que une o significante e o significado, ato cujo produto é o signo" (1997, p. 51). Identificar o Palio Weekend com as necessidades, com os sonhos, com os desejos da família exige a convergência da cor, da visualidade e de tudo quanto possa mover os sentimentos na direção dessa identificação. Peça por peça, vai-se compondo esse construto complexo de identidades e afinidades. Produz aquilo que, em $O$ óbvio e o obtuso: ensaios críticos III, Barthes (1990, p. 34) denomina mensagem operatória:

[...] nunca se encontra (pelo menos em publicidade) uma imagem literal em estado puro; mesmo que conseguíssemos elaborar uma imagem inteiramente "ingênua", a ela se incorporaria, imediatamente, o signo da ingenuidade e a ela se acrescentaria uma terceira mensagem, simbólica.

Sim, as coisas (esse automóvel) não nos é “entregue”, na peça publicitária, simplesmente em sua consistência material. Elas nos são entregues como humanamente simbólicas: símbolos que nos acabam constituindo em novos sujeitos. Linguagem dos objetos passam a se verterem em linguagem humanas. Exemplo: a tinta azul do carro, a tinta azul do vestuário ou do sapato das pessoas que compõem o quadro no que ele tem de material, se tornam linguagem humana que diz quem 
queremos ser ou quem é que alguém quer que sejamos. Assim: "Você é membro de uma 'família ideal', tal como o automóvel que você está vendo é 'ideal”. Derrida (1973) não exagera quando diz que "Não há o fora do texto". O virtual se verte no real e vice-versa. A peça publicitária-texto "nos fala" a seu modo. Só a lógica da diferença consegue acolher esta posição teórica. "Além de serem interdependentes, identidade e diferença partilham uma importante característica: elas são o resultado de atos de criação linguística" (SILVA, 2000, p. 76). A peça publicitária-texto transfunde o ideal no real das vidas realmente humanas: as pessoas. Desta mesma forma é que sustento o conceito de imagem-texto; coisa-texto; mundo-texto.

É, bem por isto, interessante notar que por mais clean que seja a ilustração que estamos a analisar, sua leitura não deixa de ser complexa e os elementos reduzidos em número compõem um texto cuja leitura demanda muita atenção e oferece sentidos múltiplos, sem deixar, contudo, de ser tematizados em torno de objetivos específicos e de um objetivo geral, neste caso, vender a Weekend a um número de pessoas maior possível. E como o sonho capitalista de consumo tem maior chance de realização, para este tipo de produto, entre as famílias de classe média, o eixo em torno do qual se constrói a mensagem que passa por ela (a família ideal para comprar esse produto ideal). Trata-se daquilo que Barthes denomina "a imagem denotada". Lembra, ainda, Barthes (1990, p. 38) que: "A diversidade das leituras não é, no entanto, anárquica, depende do saber investido na imagem (saber prático, racional, cultural, estético)". Ou, dito de outra forma pelo mesmo autor, “[...] a mesma lexia mobiliza léxicos diferentes". Porque a leitura é sempre um processo em que interagem um texto e um leitor. Um texto e muitos leitores, onde como já destaquei, os elementos culturais não são neutros. Produzem, ou induzem a produzir leituras várias (mas sem anarquia, como bem lembra Barthes). Aliás, em seu estudo intitulado "Estudos culturais: o quê e o como da investigação", Baptista (2009) toma o conceito de complexidade como uma das constantes das múltiplas metodologias dos ECs. Além dito, nada é neutro, nada se produz, em cultura, via natureza. Toda a ação cultural é ação política. Na produção da propaganda não se olha por um visor de uma câmera para captar o casual, o natural: é, bem antes, um ato criador, instituidor/destituidor. Percebemos, em minha análise, como se institui e se destitui a família. Como se institui um modelo de automóvel, determinam-se sua permanência e seu desaparecimento do mercado. A mesma análise pode ser feita para verificar como se destitui um modelo cultural qualquer. No texto intitulado "Eles são de família", da Quatro Rodas (1998, p. 410), que tem como assunto principal o modelo de automóvel Palio Weekend da Fiat, cuja propaganda é objeto 
deste estudo, encontrei um texto que diz: "MÉDIOS - Correndo por fora, o veterano Kadett levou a melhor contra Corsa e Ford Escort”, que institui e destitui, a um tempo (destitui enquanto se trata de um carro veterano e institui quando se diz que "levou a melhor" contra...). E a destituição se torna definitiva para o Kadett quando se fala sobre a "[...] falta de evolução de seu projeto" (1998, p. 44). A transitoriedade é um fenômeno e um valor de nosso tempo que demanda projetos constante e rapidamente renovados, sob pena de obsolescência rápida. Nossa cultura ocidental capitalista, consumista, põe como um dos valores o consumo. É um parâmetro cultural que a ele as coisas devem corresponder. Entre as mudanças culturais familiares que devem corresponder às mudanças dos automóveis e vice-versa está o pequeno número de filhos: o ideal é, quase sempre, um menino primeiro, depois uma menina. Se o homem/macho é um pouco atarracado... não faz tanta diferença. Mas a mulher deverá ser impreterivelmente esbelta, preferencialmente alta, uma Barbie (apesar das adequações que sofreu) e assim por diante. Nossa propaganda está em dia com estas características culturais de nosso mundo capitalista. Ao disciplinamento do corpo deve corresponder o disciplinamento do novo modelo de automóvel. Ou é o contrário? Não é nem isso, nem aquilo. São ambas as coisas que se produzem mutuamente: o automóvel reproduz a família e, esta, ao automóvel. O consumo é o denominador comum.

\section{Desenho e fotografia}

Para este estudo e análise se torna importante uma distinção entre desenho e fotografia. Barthes adverte para esta diferença:

Deve-se, pois, opor a fotografia, mensagem sem código, ao desenho, que, embora denotado, é uma mensagem codificada... o desenho não reproduz tudo, frequentemente reproduz muito pouca coisa, sem, porém deixar de ser uma mensagem forte, ao passo que a fotografia, se por um lado pode escolher seu tema, seu enquadramento e seu ângulo, por outro lado não pode intervir no interior do objeto (salvo trucagem) (BARTHES, 1990, p. 35).

Mas é justamente por este lado ideológico da fotografia que pela trucagem se podem produzir sentidos desejados, fatos não existentes na natureza fotografada, e que sua riqueza semântica tem um grande ganho. No nosso caso específico, cria o mito da família perfeita, entendido o mito no sentido que lhe conferem Adorno e Horkheimer em Dialética do esclarecimento (1985), como "produto do próprio esclarecimento", ou seja, modos de abstrair os processos de controle e dominação, os mesmos processos que o esclarecimento utiliza na modernidade. Portanto, a 
ideologia está presente e assume a forma do mito. Carro ideal, família ideal, que são, afinal, mais que mitos? "O mito é uma fala", diz Barthes (1982, p. 131) com um título de Mitologias. "Naturalmente, não é uma fala qualquer [...]". "O significante do mito apresenta-se de uma maneira ambígua: é simultaneamente sentido e forma, pleno de um lado e vazio do outro" (BARTHES, 1982, p. 139). Se, de um lado, o mito da propaganda da Weekend (o carro ideal, a família ideal) suscita o cotidiano verdadeiro, o familiar, por outro, no criar este mito, esvazia-o ao transferi-lo para outra coisa que não é a família, isto é, o automóvel. O automóvel institui a não-família ideal que o discurso ambíguo produz em forma de mito. É tão estreita a ligação entre o conceito de família ideal e de carro ideal que esta relação acaba por desconstruir qualquer verdade por tênue que seja, em torno da família ideal. Ocorre, nesta propaganda fotográfica, exatamente o processo de ideologização que Barthes atribui ao mito. Diz ele: "A semiologia ensinou-nos que a função do mito é transformar uma intenção histórica em natureza, uma contingência em eternidade. Ora, este processo é o próprio processo da ideologia burguesa" (BARTHES, 1982, p. 162). Ao criar o mito da família ideal para o carro ideal, naturaliza-se ideologicamente esta relação. A mediação entre o conceito e a materialidade destas coisas é a ideologia que as transforma em ideais, naturalizando tal relação. É a inversão a que se refere Barthes (1982, p. 163) da anti-physis que se converte em pseudo-physis. Com isto, perde-se a lembrança da produção do mito e passa-se a ver apenas natureza. Mas, em perfeito acordo com Adorno e Horkheimer, também neste caso específico, o mito já institui a ideologia capitalista.

Diante disto tudo, considero que o texto materializado na fotografia da Weekend cercada pela família ideal revela impasses de significado que viabilizam sua desconstrução ${ }^{2}$. A família ideal se converte em família real, para o carro real. Mas este fenômeno é circular (dialético). Uma espécie de gangorra semântica de inversão contínua de sentido. Se repararmos bem nas figuras, nas posturas, nas atitudes, nada encontraremos além do cotidiano. O conjunto, porém, composto por uma família em um automóvel se compõe e decompõe continuamente, por força de seus elementos componentes. Não existe nada além do cotidiano em cada figura (parte do todo) em particular. $\mathrm{O}$ todo, porém, se constitui num texto acirradamente ideológico, reforçado por uma legenda que reforça a écriture que constitui o todo: texto e imagem. E, neste caso, estamos diante de um fenômeno cuja força e importância, em nossos dias, corresponde ao que diz Judith Williamson (1978, p. 11, tradução minha): "A propagandas são um dos mais importantes fatores culturais que moldam e refletem nossa vida hoje". Na propaganda se realiza a troca de valores, uma espécie 
de câmbio de valores em correspondências simbólicas que Williamson (1978, p. 12, tradução minha) assim explica: "A propaganda traduz para nós essas afirmações de 'coisa'; elas nos são dadas como humanamente simbólicas”. A propaganda consegue fornecer estruturas capazes de verter a linguagem dos objetos em linguagem das pessoas e vice-versa. A foto da Weekend cercada da família dos usuários produz uma narrativa, um hipertexto familiar a partir de objetos: o próprio automóvel, as malas sendo colocadas no interior do automóvel, a bolsa retida pela criança no exterior da porta do carro, enfim, a indumentária dos personagens, as cores, tudo é uma materialidade que recompõe, reestrutura, retoca, recompõe a imagem em estado crítico de uma família moderna urbana, idealizando-a, remetendo-a ao mundo incorruptível das ideias platônicas e, pelo processo ideológico interno, a torna eterna, um conceito racional de perfeição e permanência. "Tomando", como diz, ainda, Williamson (1978, p. 11), “[...] o signo por aquilo que ele significa, a coisa pelo sentimento". Nada mais transitório que qualquer modelo de automóvel, que muda ao menos uma vez por ano e cada vez mais rapidamente desaparece. Contudo, a duração, a tradição e a permanência fiel da família ideal produzem e são produzidas pela propaganda que analisamos, ao mesmo tempo que reproduzem a fugacidade do consumo ${ }^{3}$. "Esta família está metonimicamente para $a$ família, como um tipo idealizado" (THWAITES; DAVIS; MULES, 1994, p. 53, tradução minha). A transitoriedade dos modelos de automóveis subverte a duração, a perenidade da família idealizada, segundo uma classe determinada.

\section{Formação/educação pela imagem}

No Brasil, a televisão chegou em 1950. Mas nem de longe chegou, então, para todos os brasileiros. O cinema já havia alcançado longínquos rincões, bem antes disto. Mas não há dúvida que a imagem invadiu, por atacado, os lares, com o advento da TV. Com ela, o mundo imagético passa a fazer parte do cotidiano diuturno de todas as gerações: dos recém-nascidos aos mais provectos dos homens e mulheres. A imagem passou a ocupar um tempo muito dilatado na formação/constituição dos sujeitos. As atuais gerações sequer podem imaginar a escassez de imagens em tempos que precedem o advento da televisão. Hoje, como se expressa Santos (2015, p. 17), “[...] as imagens medeiam as relações de crianças, adolescentes e mesmo adultos com novos saberes. Também inauguram novas expressões de subjetividade, firmando-se como componentes qualitativos para a formação das novas gerações por constituírem referência para os sujeitos”. Em escala nunca dantes 
vista e imaginada, sobremaneira com o advento do iPhones, os iPods, os iPad, os tablets e numerosos outros recursos tecnológicos disponíveis no mercado, o mundo se subverteu literalmente: o tempo e o espaço se encurtaram e nossos possíveis interlocutores que moram do outro lado do planeta podem, em tempo real, disponibilizar sua voz juntamente com sua imagem, produzindo uma estreita relação e sensação/vivência de proximidade. Assim, Santos (2015, p 18) pode afirmar:

Pode-se dizer que as imagens, de modo geral, habitam os sujeitos e, a partir de então, medeiam o relacionamento destes com o mundo, com os demais indivíduos da cultura e consigo próprios. São, antes de qualquer outra coisa, forças comunicantes íntimas dos seres humanos de longuíssima data, portanto, importantes como partes constitutivas dos saberes.

Se é bem verdade que a imagem faz parte da humanidade desde a mais remota ancestralidade, também é verdade que na contemporaneidade a gigantesca profusão e veiculação imagética nos cerca por todos os lados, 24 horas por dia e se tornam centralizadoras dos mais diferentes modos de expressão, formas de comunicação e autorreferência, dando intenso suporte às dinâmicas culturais, incluída, em especial, a educação. A imagem vem moldando as sociedades e os indivíduos intensa e persistentemente. Em consequência disto, como entende Santos (2015, p. 19-20), “[...] as imagens se formam como componentes culturais relevantes na atualidade, sobretudo se considerarmos o campo educacional que hoje se vê desafiado por um novo sujeito de conhecimento que se compõe tanto verbalmente quanto visivelmente". Mais e mais, as experiências visuais e as experiências educacionais se aproximam. A cada dia surgem renovados meios inteiramente compatíveis com os objetivos de compor a trama complexa do que se denomina educação. A imagem passou a ser subsumida na própria constituição e destituição dos sujeitos como, também, na sua formação ou deformação (os abismos da dark web). Como constitutiva das diferentes culturas e vivências socioculturais, a imagem é uma linguagem a cada dia mais expressiva, graças ao rapidíssimo avanço de suas diferentes formas e recursos de produção. Com isto, o que desde os gregos antigos se denominou escola como um locus privilegiado do ensinar e do aprender, mercê dos meios que disponibiliza a profusão de imagens, esse locus se esfacelou num número, na prática, quase infinito de loci (lugares) e tempos do ensinar e do aprender. A heterotopia se instaurou. Todos os tempos e todos os lugares, a um só tempo podem ser os espaços e os tempos da escola (de todos os níveis).

Contudo, foi tão rápida a emergência da profusão imagética e se complexificou tão rapidamente que penso em não subestimar nada e a ninguém ao entender que os educadores nos encontramos, em grande número, em estado de perplexidade. 
Esta perplexidade atinge a todos os educadores formais e informais e até naturais da criatura humana. À emergência desta realidade, o ritmo da formação e da aprendizagem do uso de tão espetacular linguagem pelos docentes lato sensu não foi de longe acompanhado a contento. Não é nenhum exagero afirmar que vivemos uma nova cultura visual. Nova, porque o visual sempre se constituiu em importante modo de acesso ao mundo, ao outro e a si mesmo, tal como, em remotos tempos, o desenho rupestre já o testemunhou. Mas o que se vê, hoje, alcançou uma escala de proporções e profundidade que parece ter-se literalmente aberto à infinitude. Diz, ainda, Santos (2015, p. 68): "O fenômeno da visualidade que se expande globalmente sinaliza para uma mudança considerável dos paradigmas que decorrem e, ao mesmo tempo, são decorrentes das transformações das formas de olhar, ver e ser visto”. Não bastasse esse olhar sobre nosso planeta e sobre si mesmos, os humanos já implantaram olhos artificiais em outros mundos que transmitem, sem cessar, imagens/textos que são verdadeiros hipertextos cuja leitura expande nossa cidadania para uma (se assim se pode dizer), cosmocidadania. Por outro lado, isto não é o anúncio de um fim, mas o anúncio de que este processo mal começou. A velha escola, lato sensu, limitada a pequenos espaços circunscritos pelo real, expandiu-se e implodiu em espaços e tempos virtuais, acessíveis à velocidade da luz. Bibliotecas virtuais gigantescas se tornaram pocketbibliotecas (com a devida permissão do termo) que se levam ao bolso, na bolsa ou se guardam em chips minúsculos, onde quer que seja. E nessas bibliotecas não se levam apenas textos convencionais estáticos. Podem ser levadas imagem e som na forma de palestras, de vídeos com os mais diversos conteúdos, que tratam de toda e qualquer área de saber de nosso interesse.

Esta é a realidade nova que condiciona o educando dos novos tempos. O que sempre se denominou escola viu seu tempo e seu espaço se expandirem, sem limites físicos, no virtual, através de uma infinidade de meios. As velhas (nem tão velhas assim) transparências que professores acumulavam para ministrar suas aulas, evanesceram. Preparação de aulas para o ano inteiro, já não mais limitadas a textos fixos, mas abertas a um sem número de possibilidades textuais em que a imagem se tornou uma possibilidade rápida, qualificada, acessível e barato. Podem estar confinadas no virtual, com possibilidades infinitas de atualizações, remodelagens, reconfigurações e em total compartilhamento com os educandos. As instituições de ensino, elas mesmas, sempre mais, colocam à disposição novos meios eletrônico-informáticos em que, além do texto convencional, além do som, a imagem estática ou dinâmica se integra, a cada dia mais intensamente, ao mundo vivido no processo que medeia entre professores e alunos: a educação. 


\section{Considerações finais}

A partir desta análise, aportei para algumas das possíveis conclusões: a peça publicitária analisada constrói uma identidade de família burguesa tradicional (branca; com predominância do gênero masculino sobre o gênero feminino, com uma posição social menor da criança; família com poucos membros e, em geral, abastada e, muitas vezes de costumes conservadores, ora mais, ora menos). O estudo evidencia que o poder é instituinte. Este estudo se voltou, de forma particular, a uma imagem. Trata-se apenas de uma amostragem que revela o potencial educativo ou não da imagem. A ideologia não está apenas em lugares privilegiados, nem é uma espécie de vilão da história: é a condição mesma para que o texto se produza, para que a comunicação se estabeleça, na diferença. Mas o que se estabelece pelo texto (que pode ser uma propaganda, apenas ilustração), se estabelece, se institui a partir de parâmetros nela privilegiados (harmonia das cores; hierarquia dos sujeitos, e assim por diante). Não há, também, neste caso, parâmetros privilegiados, tais como os do capital, os da economia. Os parâmetros culturais são muito mais complexos, muito menos localizados em pontos aparentemente estratégicos, pontos privilegiados. David Harvey (1996, p. 158), ao discorrer sobre a nova compreensão do tempo-espaço na condição pós-moderna e ao abordar a temática da dinâmica típica da sociedade do descarte, lembra, muito oportunamente, que: "Ela significa mais do que jogar fora bens produzidos (criando um monumental problema sobre o que fazer com o lixo); significa também ser capaz de atirar fora valores, estilos de vida, relacionamentos estáveis, apego a coisas, edifícios, lugares, pessoas e modos adquiridos de agir e ser". Acrescentaria mais um item à lista dos descartes, muito significativo de nossa cultura: os automóveis.

Enfim, o texto está aí para ser lido. Para ser mais que lido: consumido. Produção e consumo reproduz a circularidade ideal de quem queira estar on the top... por algum momento fugaz. Aprender a ler imagens é uma demanda premente até mesmo dos sistemas educacionais. As imagens deixaram de ser eventuais. Estão por toda parte. Basta comparar, entre muitas outras coisas, os manuais escolares, por exemplo, da década de 1960 para trás, ou nem tanto, para verificar como a imagem ocupava espaço eventual.

Sem dúvida, a fugacidade da informação no contemporâneo provoca vertigens e para não cair em desiquilíbrio, nada melhor do que familiarizar-se com a leitura da imagem, meio pelo qual boa parte da educação no contemporâneo passa. É tarefa difícil. Não fazia parte do cotidiano dos docentes há não muito tempo passado. 
No Brasil, antes da década de 1990 fazia parte de um número bem reduzido de pessoas, se levarmos em conta a emergência dos computadores e dos telefones ditos celulares. Hoje, a imagem é uma realidade que abrange praticamente a todos, até mesmo independentemente da vontade individual. Ela está em toda parte e já nem é possível ignorá-la, nem se livrar dela. Melhor é aprender a lê-la. Este artigo é um pequeno verbete desse volumoso compêndio representado pelas demandas educacionais de nosso tempo, face ao mundo imagético.

\section{Notas}

1 Elizabeth Cristina Landi de Lima e Souza e Maria Angélica Magalhães Rodrigues ([1986]), em seu texto intitulado Família e paternidade: o papel do pai na criação dos filhos, assim configuram a família da classe média: "Principalmente no âmbito da classe média, difunde-se a ideia da família 'ideal' dentro de um padrão americano, onde o pai é um trabalhador bem sucedido e a mãe, sempre feliz, é responsável pela organização do lar e pelo cuidado com os filhos, que sempre bem cuidados aguardam o pai retornar do trabalho para juntos desfrutarem os bens adquiridos e a casa bem equipada".

2 Como afirma Eagleton (2006, p. 144), "A leitura típica habitual de Derrida consiste em tomar um fragmento aparentemente periférico da obra - uma nota de rodapé, um termo ou imagem menor e repetido, uma alusão casual - e nele trabalhar tenazmente até o ponto em que ele ameace desmantelar as oposições que governam o texto como um todo. A tática de crítica desconstrutiva é em outras palavras, demonstrar como os textos podem embaraçar seus próprios sistemas lógicos dominantes. E a desconstrução mostra isso tomando os pontos 'sintomáticos', os aporia ou impasses de significado, nos quais o texto enfrenta problemas, perde a coesão esse abre a contradições”.

3 No interior do número da revista que analiso, a mesma Weekend é mostrada com uma família que acaba de descarregar o carrinho de mercado no bagageiro. O carrinho ainda está aí, símbolo e realidade do consumismo da família burguesa contemporânea: o transitório, o fugaz, como transitórias e fugazes são as mercadorias, na voragem do consumo.

\section{Referências}

ADORNO, Theodor W.; HORKHEIMER, Max. Dialética do esclarecimento. Trad. Guido Antonio de Almeida. Rio de Janeiro: Zahar, 1985.

BAPTISTA, Maria Manuel. Estudos culturais: o quê e o consumo da investigação. Carnets, cultures littéraires: nouvelles performances et dévellopement. n. spécial, automne/hiver, p. 451-461, 2009.

BARKER, Chris. Cultural studies: theory and practice. Los Angeles/London: Sage, 2008.

BARTHES, Roland. Elementos de semiologia. Trad. Izidoro Blikstein. São Paulo: Cultrix, 1997.

BARTHES, Roland. O óbvio e o obtuso: ensaios críticos III. Trad. Léa Novaes. Rio de Janeiro: Nova Fronteira, 1990.

BARTHES, Roland. Mitologias. 5. ed. Trad. Rita Buongermino, Pedro de Souza e Rejane Janowitzer. São Paulo: DIFEL, 1982.

BENJAMIN, Walter. A obra de arte na era de sua reprodutibilidade técnica. Trad. Gabriel Valladão Silva. Porto Alegre: L\&PM, 2013. 
DERRIDA, Jacques. Gramatologia. Trad. Miriam Schnaiderman e Renato J. Ribeiro. São Paulo: Perspectiva, 1973.

EAGLETON, Terry. Teoria da literatura: uma introdução. Trad. Waltensir Dutra. São Paulo: Martins Fontes, 2006.

HALL, Stuart. On ideology: cultural studies. Birmingham: Center for Contemporary Cultural Studies, 1972.

HARVEY, David. Condição pós-moderna: uma pesquisa sobre as origens da mudança cultural. 6. ed. Trad. Adail Ubirajra Sobral e Maria Stela Gonçalves. São Paulo: Loyola, 1996.

LÉVY, Pierre. O que é o virtual? 2. ed. Tradução de Paulo Neves. São Paulo: Editora 34, 2011.

LIMA E SOUZA, Elisabeth Cristina; RODRIGUES, Maria Angélica Magalhães. Família e paternidade: o papel do pai na criação dos filhos. [1986]. Disponível em: http://www.abrapso.org. br/siteprincipal/anexos/AnaisXIVENA/conteudo/pdf/trab_completo_225.pdf. Acesso em: 09 mar. 2021.

LOPES, Rui Sardinha. A imagem na era de sua reprodutibilidade eletrônica. 1995. Dissertação (Mestrado em Letras) - Faculdade de Filosofia, Letras e Ciências Humanas, Universidade de São Paulo, São Paulo, 1995.

LUTZ, Catherine; COLLINS, Jane. The photography as an intersection of gazes: the example of National Geographic. Visual Anthropology Review, Nova York, v. 7, n. 1, p. 134-149, primavera de 1991. Disponível em: https://www.researchgate.net/publication/250941250_The_Photograph_as_an_Intersection_of_Gazes_The_Example_of_National_Geographic. Acesso em: 18 ago. 2021.

PINA, Álvaro. Intellectual spaces of practice and hope: power and culture in Portugal from the 1940s to the Present. Cultural Studies - Theorizing Politics, Politicizing Theory (Intelectual Practices in Culture and Power: Transnational Dialogues), v. 17, n. 6, p. 747-766, 2003.

QUATRO RODAS. São Paulo: Abril, n. 38, 1998. Capa.

SANTOS, Cláudia Aparecida dos. As imagens como elemento problematizador em contextos pós-modernos: por uma ontologia da educação visual. 154 p. Dissertação (Mestrado em Educação)

- Universidade Comunitária da Região de Chapecó, Chapecó, 2015.

SAUSSURE, Ferdinand de. Curso de linguistica geral. 20. ed. Trad. Antônio Chelini, José Paulo Paes e Izidoro Blikstein. São Paulo: Cultrix, 1995.

SILVA, Tomaz Tadeu da. A produção da identidade e a diferença. In: SILVA, Tomaz Tadeu (org.). Identidade e diferença: a perspectiva dos estudos culturais. Petrópolis: Vozes, 2001. p. 73-102.

THWAITES, Tony; DAVIS, Lloyd; MULES, Warwick. Tools for cultural studies: an introduction. South Melbourne: Macmillan Education, 1994.

WILLIAMSON, Judith. Discording advertisements: ideology and meaning in advertising. Londres: Marion Boyars, 1978. 